\title{
Antioxidant capacity of capulin (Prunus serotina subsp. capuli (Cav). McVaugh) fruit at different stages of ripening
}

\section{Capacidad antioxidante de frutos de capulín (Prunus serotina subsp. capuli (Cav). McVaugh) a diferentes estados de maduración}

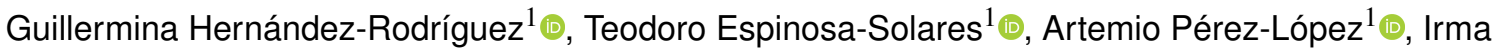 \\ Salgado-Escobar ${ }^{2}$ (0, Diana Guerra-Ramírez ${ }^{1 *}$ (0) \\ ${ }^{1}$ Universidad Autónoma Chapingo, km 38.5 Carretera México-Texcoco. CP. 56230. Texcoco, Estado de México, México. \\ ${ }^{2}$ División de Ingeniería y Arquitectura, Departamento de Física y Matemáticas. Tecnológico de Monterrey - Campus Ciudad de México. \\ Ciudad de México, México. \\ *Corresponding author: guerrard@correo.chapingo.mx
}

Scientific article received: August 02, 2018 accepted: November 13, 2018

\begin{abstract}
Prunus serotina is a species that grows wild or under cultivated conditions in several regions of the Americas, and is considered as a potential source of antioxidants. The study aimed to evaluate the concentration changes in compounds that contribute to the antioxidant capacity in capulin (Prunus serotina) fruit during the ripening process, in order to define when the maximum concentration is reached and thus establish a harvest index for the fruit. Antioxidant capacity was evaluated by spectroscopic methods. A completely randomized simple factor design was used for the statistical analysis. It was found that the content of total phenols and flavonoids decreased significantly at the S3 ripening stage (93 days after anthesis, DAA). Total anthocyanins increased significantly to $1.4 \mathrm{mg}$ Cyanidin-3-glucoside $\mathrm{g}_{d b}^{-1}$. The antioxidant capacity of the fruit had a maximum value of $63.7 \mu \mathrm{mol} \mathrm{TE} \mathrm{g}_{d b}^{-1}$ at the $\mathrm{S} 3$ ripening stage (93 DAA). Results indicated that the antioxidant capacity of the fruit is related to the content of total flavonoids and is higher before reaching the characteristic purple coloration, which is a consumption indicator.
\end{abstract}

Key words: Anthocyanins, black cherry, FRAP, maturation, wild fruit.

RESUMEN. Prunus serotina es una especie que crece silvestre o en condiciones de cultivo en diversas regiones de América, y es considerada como una fuente potencial de antioxidantes. El objetivo de esta investigación fue evaluar los cambios de concentración en los compuestos que contribuyen a la capacidad antioxidante en frutos de capulin (Prunus serotina) durante el proceso de maduración, para definir el momento en que se alcanza la máxima concentración y así establecer el índice de cosecha de los frutos. La capacidad antioxidante se evaluó mediante métodos espectroscópicos. Para el análisis estadístico se utilizó un diseño de factor simple completamente aleatorizado. Se encontró que el contenido de fenoles y flavonoides disminuyó significativamente en la etapa de maduración S3 (93 DDA). Las antocianinas totales incrementaron significativamente hasta $1.4 \mathrm{mg}$ Cyanidin-3-glucosido $\mathrm{g}_{b s}^{-1}$. La capacidad antioxidante de los frutos tuvo un valor máximo de $63.7 \mu \mathrm{mol} \mathrm{ET} \mathrm{g_{bs } ^ { - 1 }}$ en la etapa de maduración S3. Los resultados indicaron que la capacidad antioxidante de los frutos está relacionada con el contenido de flavonoides totales y es mayor antes de alcanzar la coloración purpura característica, que es un indicador de consumo.

Palabras clave: Antocianinas, cereza negra, FRAP, frutos silvestres, maduración.

\section{INTRODUCTION}

The content of antioxidant phytochemicals in many fruits has been the subject of recent research
(Jagadeeshwar 2005, Salem et al. 2018, Taher et al. 2018), such as capulin (Prunus serotina subsp. capuli), a species that grows wild or under cultivated conditions in several regions of the Americas, and 
which has attracted considerable attention as a potential source of phenolic compounds that are plentiful in the fruit skin (Ordaz-Galindo et al. 1999, RiveroCruz 2014). The plant and fruit of the Prunus serotina species have been used since pre-Hispanic times as food and for medicinal purposes due to the antioxidant, antihypertensive and antimicrobial properties that have been attributed to them (Jiménez et al. 2011, Luna-Vázquez et al. 2013).

Excessive production of reactive oxygen and nitrogen in the human body are responsible for the pathogenesis of some chronic diseases. It has been reported that the ingestion of antioxidant phytochemicals, such as the phenolic compounds present in many fruits, is inversely associated with many chronic diseases caused by oxidative stress (Zhang et al. 2015). Natural antioxidants are prized because they can be used to design functional or nutraceutical foods that provide health benefits (Villanueva-Tiburcio et al. 2010, Gürbüz et al. 2018). The changes in chemical composition and content of phytochemical compounds with the antioxidant power in fruits mainly depends on the development stage of the plant. In non-climacteric fruits, such as capulin, it is an important condition because the optimal harvest time depends on it (Kader 2002). Most of the antioxidant capacity in Prunus serotina species belongs to the group of phenolic compounds and vitamins. Some authors report that the content of these compounds in this fruit can be affected quantitatively by several factors, such as genetic differences, environmental production conditions, harvest maturity and postharvest handling conditions (Lekala et al. 2019, Zadernowski et al. 2005).To better exploit the antioxidant potential of capulin fruit, it is necessary to determine the stage of development when the highest antioxidant activity occurs, and that allows establishing a harvest index for the fruit. Therefore, the aim of this research is to evaluate the concentration changes in the compounds that contribute to the antioxidant capacity in capulin (Prunus serotina) fruit during the ripening process, in order to determine when the maximum value is reached.

\section{MATERIALS AND METHODS}

\section{Identification of herbarium specimen and fruit de- velopment evaluation}

A wild phenotype of capulin (Prunus serotina subsp. capuli (Cav). McVaugh) from Zacatlán (19 ${ }^{\circ}$ 55' 47.1" N, 98 00' 00.4" W; 2531 m), Puebla State, Mexico was studied. This species was sampled in a pine-oak forest area. A voucher specimen (No. 25499) was identified, following the Calderón and Rzedowski (2005) protocol, and kept in the Herbarium of the Universidad Autónoma Chapingo. After the trees in the study area bloomed, five branches were selected for measuring fruit growth at $0,30,45,60$, 75 , 90, and 97 days after anthesis (DAA). During sampling days, 50 fruit were taken for weight and size evaluation.

\section{Analysis of fruit growth}

The results for fresh weight, polar diameter and equatorial diameter of the fruit were subjected to polynomial regression analysis, from which models that best explain the growth of the fruit based on these variables were generated. The estimation of the models was performed using the Sigma Plot program (11.0) and selected based on the value of $R^{2}$.

\section{Chemical characterization of fruit during ripening}

For chemical fruit characterization during ripening, five harvests were taken and identified as stages (S1-S5). The fruit were collected in five stages of maturity, based on the color of the external surface: green (S1), yellow-red (S2), reddish-brown (S3), $100 \%$ reddish (S4) and reddish-purple (S5) (Figure 1). Around $200 \mathrm{~g}$ of fruit, representative of the entire population, were collected in each harvest. Skin and pulp were separated from seed, freeze-dried and ground (NutriBullet $600 \mathrm{w} 8$ ) for storing at $-5^{\circ} \mathrm{C}$. Total soluble solids were measured by refractometry on a portable refractometer with a temperature correction. A drop of pure juice from each of the three replicates containing 15 fruit was measured. The results were expressed in ${ }^{\circ}$ Brix. Titratable acidity was measured by diluting $1 \mathrm{~mL}$ of pure juice in $10 \mathrm{~mL}$ of distilled water and titrating this solution with $0.01 \mathrm{M} \mathrm{NaOH}$ at $\mathrm{pH} 8.1$. 


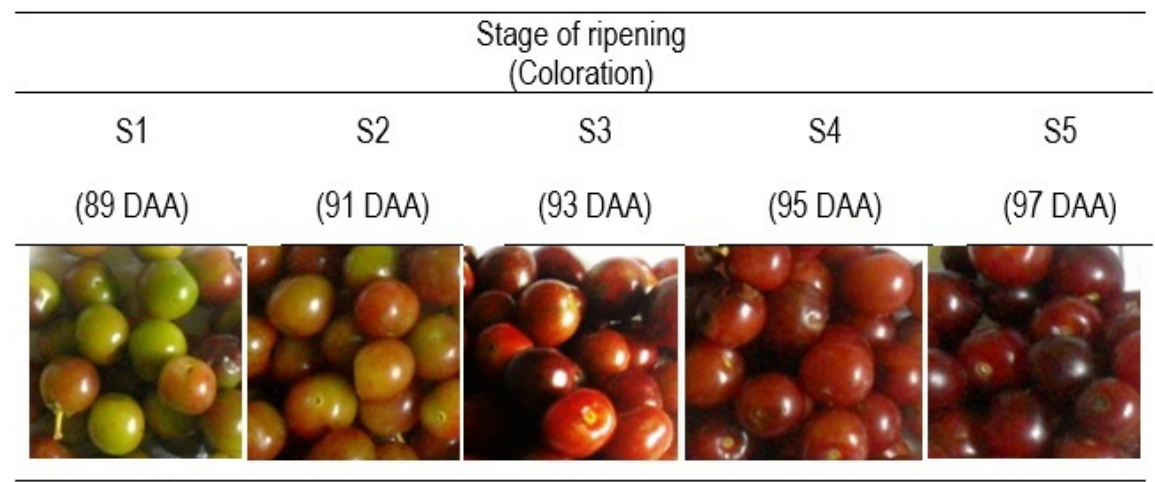

S: stage of ripening

Figure 1. Stages of ripening of capulin (Prunus serotina subsp. capuli (Cav). McVaugh). DAA: Days after anthesis.

The results were expressed in $\mathrm{mg}$ of citric acid per $\mathrm{g}$ of pulp (Neves et al. 2015).

\section{Extract preparation for phenolic and flavonoid contents and antioxidant capacity}

Extraction was performed based on the method reported by Hernández-Rodríguez et al. (2016), using ethanol/water $(1: 1, \mathrm{v} / \mathrm{v})$ as solvent. Each sample was adjusted at $\mathrm{pH} 3.3$ with $5 \% \mathrm{HCl}$ (Jiménez et al. 2011) and stirred by vortex for $3 \mathrm{~min}$ at $252 \mathrm{~g}$ (Vortex Synergy, WVR International). Then, the sample was treated under sonication (to exhaustively extract the phenolic compounds) for $15 \mathrm{~min}$ at $20^{\circ} \mathrm{C}$, using ice to maintain the temperature (Ultrasonic Cleaner 8890, Cole-Palmer). Then, the sample was shaken in an incubator (Orbital incubators Prendo INO-650 M) for $30 \mathrm{~min}$. Finally, the sample was sonicated again for $15 \mathrm{~min}$ and then centrifuged for $15 \mathrm{~min}$ at 700 g. Each sample was analyzed in triplicate. Phenolic compounds are polar substances and therefore polar organic solvents are used for their extraction and the extraction medium is acidified to favor their protonated form.

\section{Analytical methods \\ Total phenolic content}

Total phenolic compounds content was determined using the Folin-Ciocalteu reagent (Singleton and Rossi 1965) adapted to microplates. The absorbance was measured at $760 \mathrm{~nm}$ in a microplate reader (Synergy 2 Microplate reader, Biotek International, software Gen5). A gallic acid standard curve with a linear range $\left(2.5-29.0 \mu \mathrm{g} \mathrm{GA} \mathrm{mL}^{-1}\right)$ was prepared from a freshly made $0.5 \mathrm{mg} \mathrm{mL}^{-1}$ gallic acid stock solution. Results were expressed as $\mathrm{mg}$ gallic acid equivalents (GAE) per gram on dried basis (mgGAE $\mathrm{g}_{d b}^{-1}$ ).

\section{Total flavonoids content}

The total flavonoids content was determined according to Kubola and Siriamornpun (2011) adapted to microplates. Extract $(0.5 \mathrm{~mL})$, distilled water $(2.5 \mathrm{~mL})$ and $5 \% \mathrm{NaNO}_{2}$ solution $(0.15 \mathrm{~mL})$ were mixed. After 6 min, $10 \% \mathrm{AlCl}_{3} 6 \mathrm{H}_{2} \mathrm{O}$ solution $(0.3 \mathrm{~mL})$ was added; after five $\mathrm{min}, 5 \% \mathrm{NaOH}$ solution $(1 \mathrm{~mL}$ ) was added and stirred by vortex ( $3 \mathrm{~min}$, $252 \mathrm{~g})$. Absorbance of an aliquot $(200 \mu \mathrm{L})$ was measured at $510 \mathrm{~nm}$ in the microplate reader (Synergy 2 microplate reader, Biotek International, software Gen 5). A catechin standard curve within the linear range ( 0.7 to $34.5 \mu \mathrm{g} \mathrm{CE} \mathrm{mL}^{-1}$ ) was prepared from a freshly made $300 \mu \mathrm{g} \mathrm{mL}^{-1}$ catechin stock solution. Results were expressed as $\mathrm{mg}$ of catechin equivalents (CE)

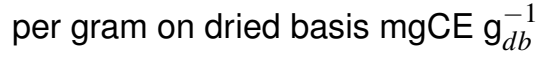

\section{Ferric-reducing antioxidant power (FRAP)}

The FRAP assay was carried out according to the method of Benzie and Strain (1996) adapted to microplates. The FRAP reagent was prepared fresh each time it was needed, from sodium acetate buffer 
(300 mM, pH 3.6), $10 \mathrm{mM}$ TPTZ solution $(40 \mathrm{mM} \mathrm{HCl}$ as solvent) and $20 \mathrm{mM}$ iron (III) chloride solution at a ratio of $10: 1: 1$, respectively. An aliquot $(20 \mu \mathrm{L})$ of a suitably diluted extract was mixed with $180 \mu \mathrm{L}$ of FRAP solution and $60 \mu \mathrm{L}$ of distilled water. The absorbance was measured at $595 \mathrm{~nm}$ in a microplate reader (Synergy 2 microplate reader, Biotek International, software Gen 5). A Trolox standard curve with a linear range (3.8 to $46 \mu \mathrm{M}$ ) was prepared from a freshly made $1 \mathrm{mM}$ Trolox stock solution. The results were expressed as micromole Trolox equivalents per gram on dried basis $\left(\mu \mathrm{mol} \mathrm{TE}_{d b}^{-1}\right)$.

\section{Total anthocyanin content}

Monomeric anthocyanin content of the capulin fruit was measured using a spectrophotometric $\mathrm{pH}$ differential protocol (Giusti and Wrolstad 2001). One portion of $20 \mathrm{mg}$ of the sample was mixed thoroughly with $5 \mathrm{~mL}$ of a pH 1 buffer $(0.025 \mathrm{M} \mathrm{KCl})$. The absorbance of the mixture was measured at 510 and $700 \mathrm{~nm}$ using a microplate reader (Synergy $2 \mathrm{mi}-$ croplate reader, Biotek International, software Gen 5). Another $25 \mathrm{mg}$ portion of the sample was combined similarly with $5 \mathrm{~mL}$ of a pH 4.5 buffer $(4.5 \mathrm{M}$ $\mathrm{CH}_{3} \mathrm{COONa}$ ); the absorbance of this solution was measured at the same wavelengths. The anthocyanin content was calculated based on Cyanidin-3-Oglucoside, molar extinction coefficient of 26,900 and a molecular weight of $449.2 \mathrm{gmol}^{-1}$. Results were expressed in terms of $\mathrm{mg}$ Cyanidin-3-O-glucoside equivalent per gram on dried basis (mg Cyanidin-3glucoside $\mathrm{g}_{d b}^{-1}$ )

\section{Statistical analysis}

All assays were carried out in five replicates. The experimental unit was a capulin tree. A completely randomized simple factor design was applied to data; when suitable, means were compared by Tukey's test at $p \leq 0.05$. All statistical analyses were made using the program SAS version 9.1. The data were presented as the mean \pm standard error of the mean.

\section{RESULTS}

\section{Fruit development}

Fruit growth with respect to polar and equatorial diameter was best described with the use of thirddegree polynomial models (Figure 2). Fruit weight was best described by a second-degree polynomial model (Figure 2). In general, the growth of the fruit for evaluated variables presented three stages: the first of maximum or exponential growth (0-45 DAA); the second of less growth (45-75 DAA) and the third, again, of fast growth (75-97 DAA). This last stage of growth belongs to the change of color in the fruit. The growth patterns of the two diameters were similar; however, during fruit development and maturation, the growth of the polar diameter exceeded the equatorial diameter (1.1 and $1.2 \mathrm{~cm}$, respectively).

The titratable acidity of capulin fruit changed significantly from 1.2 to $0.5 \mathrm{mg}$ of citric acid equivalents per gram of fresh fruit (Table 1). The total soluble solids (TSS) content increased significantly from 6.3 to $10.1^{\circ}$ Brix from S1 to S5 (89 to 97 DAA, Table 1). The TSS/TA ratio ranged significantly from 5.52 to 19.63 , and an increase was observed in fruit ripening.

\section{Changes in the concentration of antioxidants during maturation}

The total phenolic content reached a maxi-

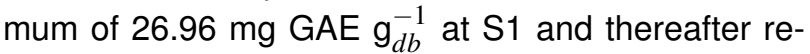
mained without significant changes until S3; however, from this time it began to decrease until reaching an average concentration of $14.40 \mathrm{mg} \mathrm{GAE} \mathrm{g}-1 b$ at S4 (Table 1). The total flavonoid content had no significant variation ( $p>0.05$ ) up to $S 3$; the maximum value was $16.56 \mathrm{mgCE} \mathrm{g}_{d b}^{-1}$. Then, the content decreased significantly to $9.23 \mathrm{mgCE} \mathrm{g}_{d b}^{-1}$. Total anthocyanins increased significantly $(p<0.05)$, from 0.04 (S1) to $1.4 \mathrm{mg}$ Cyanidin-3-glucoside $\mathrm{g}_{d b}^{-1}$ (S5), during the ripening period of the berries in the tree. The highest increase (approximately $1 \mathrm{mg}$ Cyanidin-3-glucoside $\mathrm{g}_{d b}^{-1}$ ) was observed in the last stage of ripening (S4S5), which corresponds to a change in color, from reddish to purple on the fruit skin. The antioxidant capacity of the fruit had a maximum value of $63.7 \mu \mathrm{ol}$ $\mathrm{TE}_{d b}^{-1}$ at S3. From that date it fell significantly to 32.7 
Hernández-Rodríguez et al.

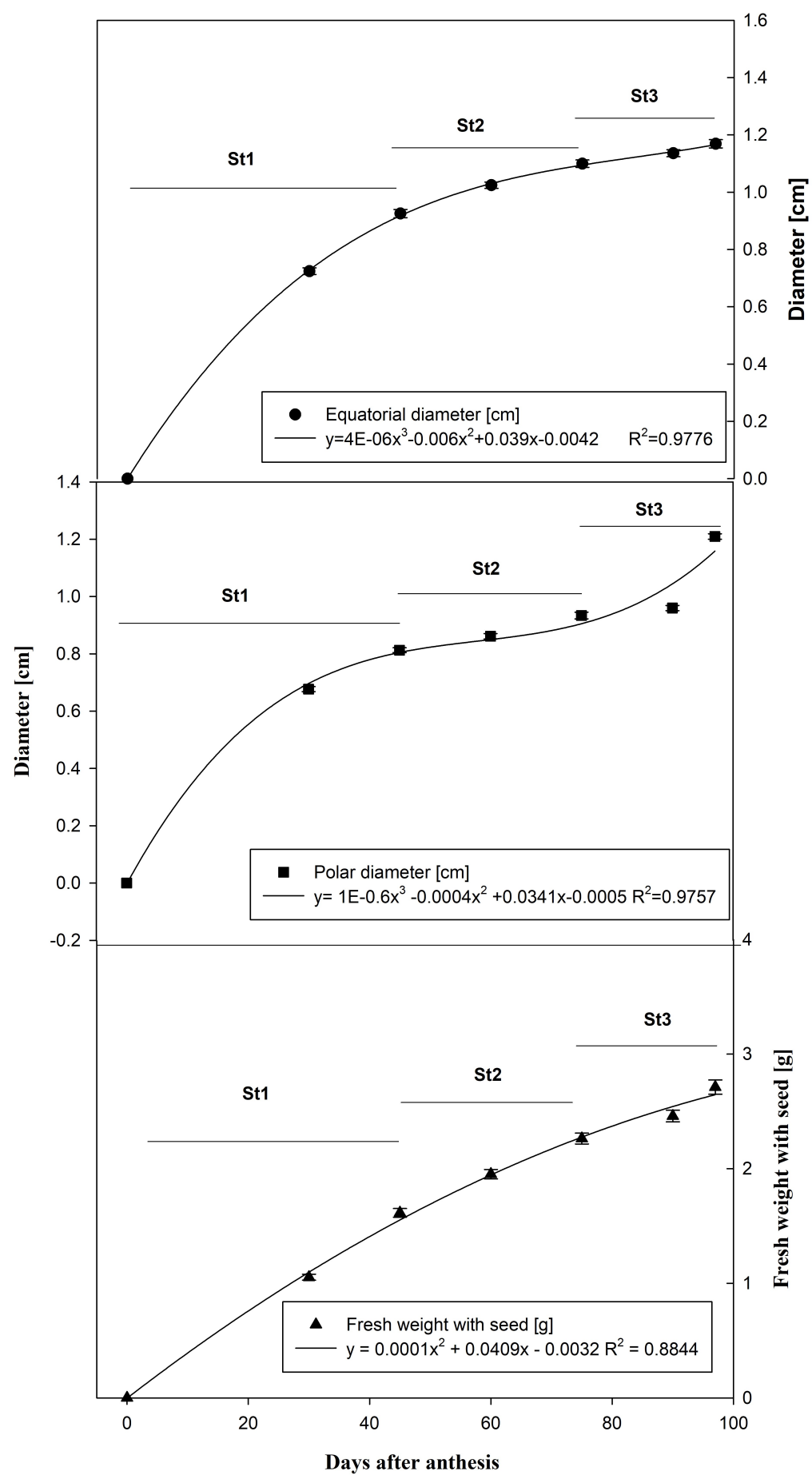

Figure 2. Fresh weight and equatorial and polar diameters of capulin (Prunus serotina subsp. capuli (Cav). McVaugh) fruit during development. St1: exponential growth, St2: less growth and St3: fast growth. 
Table 1. Content of total phenols, total flavonoids, antioxidant capacity, anthocyanins, total soluble solids, titratable acidity and TSS/TA in fruit of Capulin (Prunus serotina subsp. capuli (Cav). McVaugh) at different stages of ripening.

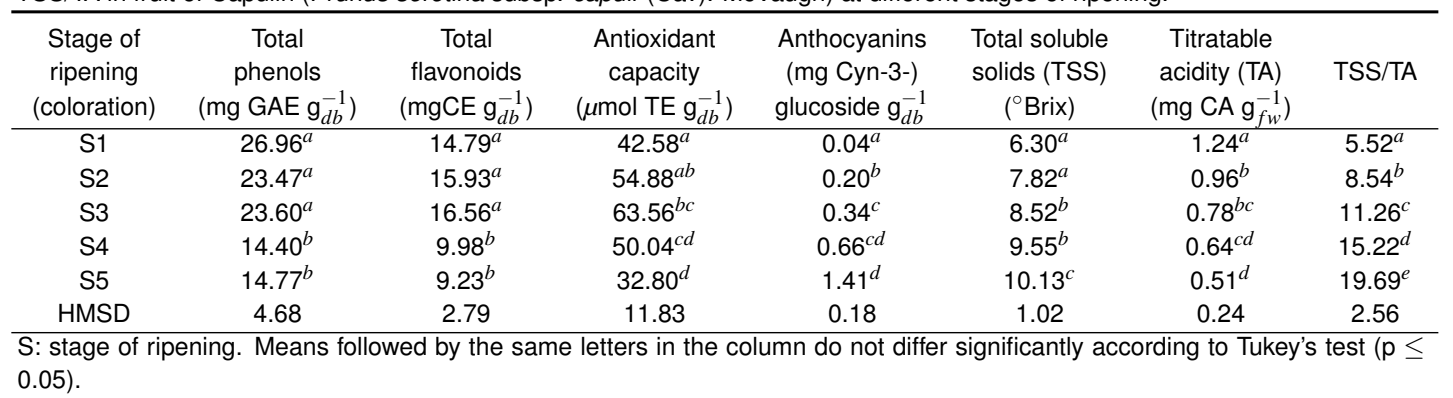

$\mu \mathrm{mol} \mathrm{TE} \mathrm{g}_{d b}^{-1}$ at the S5 ripening stage (day 97).

\section{DISCUSSION}

\section{Fruit development}

The behavior observed is typical of stone fruits, where the first stage has greater growth because there is an overlap in the growth of the stone and pulp (Díaz et al. 2017). According to Hernández et al. (2002), fruit growth begins with the cell division process and results in a weight increase. In peach fruit three growth stages were also detected: stage I lasted from flowering to the beginning of stone hardening. This phase was characterized by a period of intense cell division, starting from fruit set. Stage II was characterized by a slow increase in the mesocarp, since the most relevant process is lignification (stone hardening). Stage III started once the stone hardened completely and was characterized by a marked elongation of the cells. Therefore, there is an accelerated growth in size and fruit weight (Ojer 2011).

The observed titratable acidity behavior can be explained according to Neves et al. (2015) who reported that the decrease in titratable acidity during fruit ripening can be attributed to both the use of organic acids in the respiration process and the result of the dilution effect that occurs during fruit growth. The TSS content had the opposite behavior to titratable acidity. According to Eskin and Hoehn (2013), as the maturation process occurs in fruits, the TSS content increases due to the action of the polygalacturonases and cellulases enzymes involved in the degradation of the pectin and cellulose in the cell wall. The TSS/TA ratio had an increase throughout fruit ripening; this coincides with Vursavuş et al. (2006) who reported a TSS/TA ratio ranging from 20.09 to 29.49 for three varieties of sweet cherry (Prunnus avium L.) harvested at commercial maturity. According to Siegmund (2015), the development of the flavor in fruits is due to an increase in sweetness and a decrease in acidity resulting in a suitable sugar/acid ratio.

\section{Changes in the concentration of antioxidants during maturation}

The behavior observed in total phenolic content is similar to the ones reported for fruits of raspberries (Rubus idaeus L. cv. Polka) (Ali et al. 2011), Vaccinium corymbosum L. (Castrejón et al. 2008) and Eriobotrya japonica Lindl. (Ding et al. 2001). It is common, during fruit development and maturation, to find strong variations in the phenolic compounds. Those variations depend on: the availability of precursors of phenolic molecules, especially phenylalanine; the activity of enzymes involved in the biosynthesis, interconversion and degradation of phenolic molecules; the changes that occur in the cell structure during fruit maturation and the effect of external factors (Macheix and Fleuriet 1990).

Regarding flavonoid content, Lou et al. (2012) reported a similar trend during fruit development in the species Morus alba L., where the most abundant flavonoid was proanthocyanidin, which decreased during fruit development but increased during the maturation stage. Similarly, Kennedy et al. (2002) reported that there is an increase in the amount of 


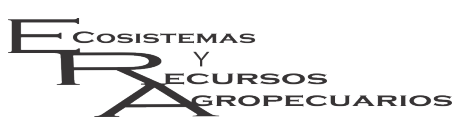

anthocyanidin incorporation into proanthocyanidins in the skin of Vitis vinifera L. berries during the ripening stage, which results in an increase in the amount of total flavonoids at this stage. On the other hand, the increase in anthocyanin content is strongly related to reddish coloration. Research on strawberries found an increase in anthocyanin content when the fruit change to a reddish or purple color in the final stage of ripening (Castrejón et al. 2008, Villanueva-Tiburcio et al. 2010, Alí et al. 2011).

The antioxidant capacity trend observed during ripening was similar to other studies on fruits of Vaccinium corymbosum L., Morus alba L. (Castrejón et al. 2008) and Myrciaria dubia (H.B.K) McVaugh (Villanueva-Tiburcio et al. 2010); in all cases it was found that antioxidant activity decreased in the final stage of fruit maturation. When comparing the results found in this work, during the fruit development stage, with those reported for the different varieties of Rubus sp., Rubus idaeus L., Rubus occidentalis L. and Fragaria $\times$ ananassa D, it was observed that in both studies, in the final maturation stage, there was a downward trend in total phenolic content, flavonoids and antioxidant capacity, while total anthocyanins increased significantly (Table 1 ). The appearance of color in the fruit is explained by the final stage of the anthocyanin biosynthetic pathway, where the enzyme flavonoid-4-reductase reduces dihydroflavonols to leucoanthocyanidins, which undergo oxidation, dehydration and glycosylation with sugars such as Dglucose, lactose, L-rhamnose and D-xylose to form anthocyanins (Eskin and Hoehn 2013).

Thus, the incorporation of flavonoids and sugars to biosynthesis anthocyanins may explain the decrease in total phenolics and flavonoids, as well as the increase in anthocyanins. Kähkönen et al. (2001) and Kader (2002) indicate that the different stages of fruit development and maturation affect the phenolic profile, as these phenolic compounds have a high content in young fruits, but decrease during maturation, with the exception of anthocyanins that generally accumulate in this last stage.

The contribution of phenolic compounds to antioxidant activity is variable; in fruit of the species Vaccinium L. sp. (Connor et al. 2002), it is reported that the antioxidant capacity is strongly related to the content of phenolic compounds and anthocyanins, while in the species Morus alba L. (Lou et al. 2012) it is reported that there are other components, different from anthocyanins and flavonols, that contribute to this activity in the last stages of fruit ripening. In Vaccinium corymbosum L., it is reported that phenolic compounds other than anthocyanins can contribute positively to total antioxidant activity (Castrejón et al. 2008).

The antioxidant capacity showed a higher correlation with the total flavonoid content $(0.72$, Pearson's correlation). Flavonoids are positively related to total phenolic content and negatively related to anthocyanin content $(0.92,-0.84$, Pearson's correlation). Although the behavior of the anthocyanins is ascending, the proportion in which they are found with respect to the flavonoid content is lower. In a capulin fruit study, a total of 2433 phenolic compounds were identified and quantified, with only 89 corresponding to cyanidin glycosides, whereas most correspond to catechin, dimeric epicatechin, trimeric proanthocyanidins, and quercetin glycosides (Vasco et al. 2009). Considering the above, it is probable that in this study the presence of phenolic compounds is responsible for the antioxidant capacity in the fruit. The results in this research showed the importance of establishing a harvest time, especially to take advantage of the antioxidant power of the fruit. In this sense, it is important to determine a suitable harvest index for the fruit, because as already shown, over-ripening contributes to the loss of its functional properties and antioxidant capacity (Gruz et al. 2011). In this case the fruit reached maximum antioxidant capacity when it was completely reddish (S3).

\section{CONCLUSIONS}

The experimental evidence showed that total phenolic and flavonoid contents, as well as antioxidant capacity decrease in capulin fruit in the last stages of ripening. Therefore, it is suggested that the ideal stage at which the fruit should be harvested is the S3 ripening stage (93 DAA), because in this stage the fruit contained the maximum concentration of pheno- 
lics and flavonoids, which means the highest antioxidant capacity.

\section{ACKNOWLEDGEMENTS}

The authors gratefully acknowledge the funding support provided by Universidad Autónoma Chapingo (Project 17086-C). Authors express their gratitude to Bioprocesses and Natural Products Research Groups for their collaboration in this research.

\section{LITERATURE CITED}

Ali L, Svensson B, Alsanius BW, Olsson ME (2011) Late seasen harvest and storage of Rubus berries-Mayor antioxidant and sugar level. Scientia Horticulturae 129: 376-381.

Benzie IFF, Strain JJ (1996) The ferric reducing ability of plasma (FRAP) as a measure of "antioxidant power": The FRAP assay. Analytical Biochemistry 239: 70-76.

Calderón RG, Rzedowski J (2005) Flora fanerogámica del Valle de México. 2a. Ed., 1a reimp. Instituto de Ecología, Comisión Nacional para el Conocimiento y Uso de la Biodiversidad. Pátzcuaro, Michoacán, México. 1406p.

Castrejón ADR, Eichholz I, Rohn S, Kroh LW, Huyskens-Keil S (2008) Phenolic profile and antioxidant activity of highbush blueberry (Vaccinium corymbosum L.) during fruit maturation and ripening. Food Chemistry 109: 564-572.

Connor AM, Luby JJ, Hancock JF, Berkheimer S, Hanson EJ (2002) Changes in fruit antioxidant activity among blueberry cultivars during cold-temperature storage. Journal of Agricultural and Food Chemistry 50: 893898.

Díaz MJ, Chairez HI, Gurrola RJN, Proal NJB, González GMC, Castellanos PE (2017) Growth models of peach fruit Prunus pérsica (L) in three handling systems. Interciencia 43: 597-602.

Ding CK, Chachin K, Ueda Y, Imahori Y, Wang CY (2001) Metabolism of phenolic compounds during loquat fruit development. Journal of Agricultural and Food Chemistry 49: 2883-2888.

Eskin NAM, Hoehn E (2013) Fruits and vegetables. In: Eskin NAM, Shahidi F (Eds.) Biochemistry of foods. Third Edition. Academic Press. San Diego, CA, USA. pp: 49-126.

Giusti MM, Wrolstad RE (2001) F1.2.1-F 1.2.13. Characterization and measurement of anthocyanins by UVvisible spectroscopy. Current Protocols in Food Analytical Chemistry, John Wiley Inc. Doi: 10.1002/0471142 913.faf0102s00.

Gruz J, Ayaz FA, Torun H, Strnad M (2011) Phenolic acid content and radical scavenging activity of extracts from medlar (Mespilus germanica L.) fruit at different stages of ripening. Food Chemistry 124: 271-277.

Gürbüz N, Uluişik S, Frary A, Frary A, Doğanlar S (2018) Health benefits and bioactive compounds of eggplant. Food Chemistry 268: 602-610.

Hernández-Rodríguez G, Espinosa-Solares T, Hernández-Eugenio G, Villa-García M, Reyes-Trejo B, GuerraRamírez D (2016) Influence of polar solutions on the extraction of phenolic compounds from capulín fruits (Prunus serotina). Journal of the Mexican Chemical Society 60: 73-78.

Hernández GMS, Arjona DHE, Coba B, Fischer G, Martínez WO (2002) Crecimiento físico y anatómico del fruto de arazá (Eugenia stipitata Me Vaugh). Agronomía Colombiana 19: 13-21. 
Jagadeeshwar RR, Sampath KU, Venkat RS, Tiwari AK, Madhusudana RJ (2005) Antioxidants and a new germacrane sesquiterpene from Carissa spinarum. Natural Product Research 19: 763-769.

Jiménez M, Castillo I, Azuara E, Beristain Cl (2011) Antioxidant and antimicrobial activity of capulin (Prunus serotina subsp capuli) extracts. Revista Mexicana de Ingeniería Química 10: 29-37.

Kader AA (2002) Postharvest technology of horticultural crops, agriculture and natural resources. Illustrated Edition. University of California. USA. 525p.

Kähkönen MP, Hopia Al, Heinonen M (2001) Berry phenolics and their antioxidant activity. Journal of Agricultural and Food Chemistry 49: 4076-4082.

Kennedy JA, Matthews MA, Waterhouse AL (2002) Effect of maturity and vine water status on grape skin and wine flavonoids. American Journal of Enology and Viticulture 53: 268-274.

Kubola J, Siriamornpun S (2011) Phytochemicals and antioxidant activity of different fruit fractions (peel, pulp, aril and seed) of thai gac (Momordica cochinchinensis Spreng). Food Chemistry 127: 1138-1145.

Lekala CS, Madani KSH, Phan ADT, Maboko MM, Fotouo H, Soundy P, et al. (2019) Cultivar-specific responses in red sweet peppers grown under shade nets and controlled-temperature plastic tunnel environment on antioxidant constituents at harvest. Food Chemistry 275: 85-94.

Lou H, Hu Y, Zhang L, Sun P, Lu H (2012) Nondestructive evaluation of the changes of total flavonoid, total phenols, ABTS and DPPH radical scavenging activities, and sugars during mulberry (Morus alba L.) fruits development by chlorophyll fluorescence and RGB intensity values. Food Science and Technology 47: 19-24.

Luna-Vázquez F, Ibarra-Alvarado C, Rojas-Molina A, Rojas-Molina J, Yahia E, Rivera-Pastrana D, et al. (2013) Nutraceutical value of black cherry prunus serotina Ehrh. Fruits: antioxidant and antihypertensive properties. Molecules 18: 14597-612.

Macheix JJ, Fleuriet A (1990) Fruit phenolics. Taylor and Francis. Boca Raton, Florida, USA. 390p.

Neves LC, Silva VXd, Pontis JA, Flach A, Roberto SR (2015) Bioactive compounds and antioxidant activity in pre-harvest camu-camu [Myrciaria dubia (H.B.K.) Mc Vaugh] fruits. Scientia Horticulturae 186: 223-229.

Ojer M (2011) Producción de duraznos para industria. Facultad de Ciencias Agrarias, Universidad Nacional de Cuyo. Argentina. 229p.

Ordaz-Galindo A, Wesche-Ebeling P, Wrolstad RE, Rodriguez-Saona L, Argaiz-Jamet A (1999) Purification and identification of capulin (Prunus serotina Ehrh) anthocyanins. Food Chemistry 65: 201-206.

Rivero-Cruz B (2014) Simultaneous quantification by HPLC of the phenolic compounds for the crude drug of Prunus serotina subsp. capuli. Pharmaceutical Biology 52: 1015-1020.

Salem IB, Ouesleti S, Mabrouk Y, Landolsi A, Saidi M, Boulilla A (2018) Exploring the nutraceutical potential and biological activities of Arbutus unedo L. (Ericaceae) fruits. Industrial Crops and Products 122: 726-731.

Siegmund B (2015) Biogénesis of aroma compounds: falvour formation in fruits and vegetables In: Parker JK, Elmore JS, Methven L (eds). Flavour development, analisis and perception in food and Beverages. Woodhead Publishing. Elsevier Ltd. Uk. pp: 127-149.

Singleton VL, Rossi JA (1965) Colorimetry of total phenolics with phosphomolybdic-phosphotungstic acid reagents. American Journal of Enology and Viticulture 16: 144-158.

Taher MA, Tadros LK, Dawood DH (2018) Phytochemical constituents, antioxidant activity and safety evaluation of kei-apple fruit (Dovyalis caffra). Food Chemistry 265: 144-151. 
Vursavuş K, Kelebek H, Selli S (2006) A study on some chemical and physico-mechanic properties of three sweet cherry varieties (Prunus avium L.) in Turkey. Journal of Food Engineering 74: 568-575.

Vasco C, Riihinen K, Ruales J, Kamal-Eldin A (2009) Phenolic compounds in Rosaceae fruits from Ecuador. Journal of Agricultural and Food Chemistry 57: 1204-1212

Villanueva-Tiburcio JE, Condezo-Hoyos LA, Asquieri ER (2010) Antocianinas, ácido ascórbico, polifenoles totales y actividad antioxidante, en la cáscara de camu-camu (Myrciaria dubia (H.B.K) McVaugh). Food Science and Technology 30: 151-160.

Zadernowski R, Naczk M, Nesterowicz J (2005) Phenolic acid profiles in some small berries. Journal of Agricultural and Food Chemistry 53: 2118-2124.

Zhang Y-J, Gan R-Y, Li S, Zhou Y, Li A-N, Xu D-P, et al. (2015) Antioxidant phytochemicals for the prevention and treatment of chronic diseases. Molecules 20: 21138-21156. 